\begin{tabular}{c} 
Volume and Issues Obtainable at Center for Sustainability Research and Consultancy \\
Responsible Education, Learning and Teaching in Emerging Economies \\
ISSN: 2708-4310 \& (E): 2708-4183 \\
Volume 3: No.1, June 2021 \\
CSRᄃ \\
Journal homepage: www.publishing.globalcsrc.org/relate \\
\hline
\end{tabular}

\title{
Analysis of the Effect of Government Expenditures on School Enrollment in Pakistan
}

Muhammad Idrees, Faculty of Business and Economics, Abdul Wali Khan University Mardan, KP, Pakistan

Farah Khan, Institute of Education \& Research, Women University Mardan, KP, Pakistan Muhammad Sofian Bin Omar Fauzee, School of Education, University Utara Malaysia, 06010 UUM Sintok, Kedah Darul Aman, Malaysia

*Corresponding author's email: drfarah@wumardan.edu.pk

\begin{tabular}{l}
\hline ARTICLE DETAILS \\
\hline History \\
Revised format: May 2021 \\
Available Online: Jun 2021 \\
\\
\hline Keywords \\
Gross national product, \\
Government expenditures, \\
School Enrolment, \\
Pakistan.
\end{tabular}

JEL Classification A20, A21 \begin{abstract}
Purpose: No one can deny the importance of education as it not only improves living standard but also promotes self-esteem as well as improves social development. The role of the government cannot be overlooked in the development of education. Therefore, the main purpose of this study is to analyses the role of government through national income and government expenditure on education through school enrolment in Pakistan. Design/Methodology/Approach: We have used secondary data over the period of 2000 to 2017 for empirical analysis. We used descriptive statistics analysis, and the method of least squares is used to obtain empirical results.

Findings: The result shows that national income and government expenditures have positive effects on school enrollment, indicating when national and government expenditures increase, ultimately school enrolment also increases in the country.

Implications/Originality/Value: Our results of this study suggest that national income needs to be increases and government spending also needs to be increases in order to improve education in the country.
\end{abstract}

(C) 2021 The authors, under a Creative Commons Attribution

NonCommercial 4.0

Recommended citation: Idrees, M., Khan, F. and Omar Fauzee, M. S. B. (2021). Analysis of the Effect of Government Expenditures on School Enrollment in Pakistan. Responsible Education, Learning and Teaching in Emerging Economies, 3(1), 27-35.

\section{Introduction}

Education empowers the human through knowledge, training, skills and smooth's her/his personality, attitudes, talents, and behaviors. It creates awareness, patience, self-esteem and confidence in people because of their rights. Education is one of the valuable factors to evaluate the level of a society (UNDP, 1990). There are several advantages of education and thereby has positive effect on overall quality of our life. An educated individual is a capital for almost any 
country. On one hand, he/she can assess better prospects for him or herself and on the other hand, the whole nation can have benefited from their work (Tripathi, 2014). Initially many countries have an initial barrier for economic growth. Due to the expansion of primary scheduling in the fight against poverty, it is broadly recognized in the fight against poverty. However, developing countries face their efforts in increasing the efforts of increasingly increasing educational services due to population and strong public budget. In addition, public education costs are frequently used inadequate, providing school structures, where you are unacceptable, pay teachers who cannot be illegally or deported, and provide school supplies. There are insufficient and bad diseases (Paterno et al., 2001).

The constructive role plays by education cannot be ignored in establishing human development. It increases the output and ability of individuals, and thus produces expert disappointment, which is led by the economy in the direction of viable economic progress. As several other developing economies, Pakistan's education system is not very promising. Low level rates at regional levels, wide equality between regions and sexes, lack of trained teachers, paucity of proper teaching materials, and poor physical infrastructure of schools indicate poor performance of this sector. The exceptionally low level of public education is the main reason for the poor performing of the Pakistani education sector. Prior to 1984-85 public outlay on education was less than 2 per cent of the GNP. In recent years, it has increased 2.2 per cent. In addition, the appropriation for government funds is indicated in higher education so that the public benefits of education should be converted into a higher upper class. Many educated educates go abroad to find higher education or opportunities for better employment. Most of them do not return and massacre masses (Memon, 2007). Several previous studies highlighted the role of government in promoting schooling/education in development and developing countries (Azam \& Ahmad, 2015; Muhammad \& Chandra, 2014; Muhammad et al., 2015; Azam, 2016; Muhammad, 2015; Rehman et al., 2018; Sajjad et al., 2018; Azam et al. 2020, Faizi et al, 2020, Azam, 2020; 2021, Akbar et al. 2021, Azam and Feng (2021), Rehman \& Khan, 2021, Haseeb \& Muhammad, 2021). In Their study Khan and Irshad (2018) mentions that good and capable teachers not simply make students attention worthy about school and knowledge, but also make them good in nation's builder.

The failure of the educational sector in Pakistan has prevented financial input, low-level performance, and surveillance monitoring, and education. Consequently, the world is the lowest rate of Global literacy, and is the lowest in countries of relatively resource and social-economic conditions. With a personal income of more than US\$ 450 people, there is an adult rate of 49 per cent of adults in India, whereas 94 per cent and 52 per cent of the inflation rate (Human Development Centre, 1998) between both Vietnam and India with low proportional income. In urban areas and Sindh and Punjab provinces, high income groups and men. "Primary education in a brief budget statement, the Ministry of Finance also mentioned that the Government of Pakistan has allocated Rs 10.12 billion for pre-primary and primary education affairs in budget FY201819 as against to Rs 8.748 billion for FY2018. Secondary education Statistics also show that Rs 12.365 billion allocated for Secondary Education Affairs \& Services for FY2018-19, which was previously Rs 10.798 billion for FY2018" (Kazmi, 2018). According to Government of PakistanEconomic Survey, the overall literacy rate in Pakistan during 2013-14 was estimated 58\%. The literacy rate estimated at $60 \%$ in $2012-13$, has declined to $2 \%$ in $2013-14$, and recorded the same percentage $2017-18$ means $58 \%$. Table 1 show literacy by province and gender.

Table 1: Literacy Rate by Province

\begin{tabular}{lllll}
\hline year & Province & Literacy rate & Male & Female \\
\hline KP & $53 \%$ & 72 & 36 \\
\hline
\end{tabular}




\begin{tabular}{lllll}
\hline \multirow{2}{*}{$2013-14$} & Punjab & 61 & 71 & 52 \\
& Sind & 56 & 67 & 43 \\
& Baluchistan & 43 & 59 & 25 \\
& KP & 53 & 72 & 36 \\
& Punjab & 62 & 72 & 54 \\
& Sind & 55 & 67 & 44 \\
& Baluchistan & 41 & 56 & 24 \\
& KP & 88 & & \\
& Punjab & 93 & & \\
& Sind & 78 & & \\
& Baluchistan & 60 & & \\
& Source: Economic survey Pakistan (various issues)
\end{tabular}

Source: Economic survey of Pakistan (various issues)

The main objectives of the study in hand are to examine that whether government spending increases educational development or otherwise in Pakistan. The result of the study is structured as follows: Section 1 deals with review of literature. Section 3 deals with data collection and methodology. Section 4 presents result of the study. Finally, section 5 concludes the study.

\section{Review of Literature}

Though there are numerous studies on education, school enrolment but studies on the impact of public spending on school enrolment are very scarce, especially in the context of Pakistan. For instance, the study of Shayan (2015) examines the unequal access of females and males in primary, secondary and higher education, and presented the main obstacles that prevent women or girls from having access to education. This study was based on a quality way by using an international and national organizations, such as UNESCO, USAID, Oxford, World Bank, Ministry of Education, and Afghanistan's Higher Education. Study was done on education situation, which has very poor state and lack of appropriate and effective policies. It has come to know that the quality of women in education, especially in high levels, is significantly lower than men. The study also concluded that fear of kidnapping or kidnapping in insecure areas reduces women's involvement in schools and parents are afraid to separate their daughter's / separately. This study has been pointed out that the main problem of women's birth is very fertile, and discrimination arises from most religious beliefs and traditions. A healthy child improves the school performance but mostly the child health and child schooling reflect the behavioral choices. Therefore, Alderman et al. (2001) conducted study on child health and school enrollment in rural Pakistan. The result of the study is that three times the child's health (nutrition) was important for entry compared to null estimates such as priorities and health facilities. In addition, there are many social and economic effects suggested by (Arif et al., 1999) that the increase in domestic income will increase the entry into the elementary school. A long way to reduce primary school registration and reducing the difference between the entry rate of boys and girls can be gone. However, healthy children determining the role of income and school enrollment.

Brown (1999) conducted study on the relationship between democracy and the accumulation of human capital in the developing world. The author used the 16 years panel data from 136 countries. Primary school entry for experimental analysis was regretted on the income, democracy and per person GDP using complex and consistent models to identify democracy. The result of the study shows that there is a major impact on the basic school entry in individual rights and electoral contests. The result further suggests that by selecting electoral preference, democratic politicians face electoral pressure, and emphasize on providing minimum educational 
opportunities for their citizens. The democratic system is often criticized by politicians by the society's failures to anger, to the extent that the pluralism of the human capital creates economic growth, an important advantage in democracy to promote the demands of popularity. Stasavage (2005) investigates that democratic matters for public spending in poor Republicans. This democratically elected African government has spent more on basic education, while spending on universities is not affected by democracy propose that poor democrats enter a large part of the school's population compared to their population counterparts.

Gupta and Vervoyeven (2001) analyses the impact of government spending on education and health. Statistics were collected in Africa's 37 countries and compared to sample countries in the Asia and West Ground. The author used the free disposable slowdown analysis based on the concept of X-Efficiency (Labenstein, 1966) to determine the performance of government spending on education and health. Paper Variable Power Equity, GDP and social indicators are buying. The result shows that the average, African countries are less effective than the African countries and the West Central. Poterba (1997) examines public expenditure for every child of the United States during the period of 1960-1990, to find out that the lack of scientific growth in a state has reduced scientific academic spending are connected. In addition, it has been pointed out that the impact of the quorate size should be influenced by the transfer of government intervention to analyse how our size affects economic well-being. However, education and health expenses in Africa countries have improved since mid-1980s. The study further states that the improvement in academic achievements and health production in African countries is much higher than the higher budget estimates. Craigwell et al. (2012) finds that that health spending has a significant positive impact on health status, while expenditure on education has no substantial effect on either secondary or primary school enrolment in 19 Caribbean countries. While, the study of Khaliq and Ahmad (2016) concludes that Pakistan's overall government expenditures on education looks to provide short-term improvements by providing rudimentary infrastructure; nonetheless, the aspect of long-term improvement in term of expansion of human resources with physical capital is disappeared. Some more related studies on the impact of government spending on school enrollment are given in Table 2.

Table 2: Previous Selected Studies the Impact of Government Spending on School Enrollment

\begin{tabular}{|c|c|c|c|c|}
\hline Authors & Time Period/Countries & Methods & Dependent Variable & Independent variable \\
\hline Shayan (2015) & $\begin{array}{l}\text { 2002-2012, Afghanista } \\
\mathrm{n}\end{array}$ & qualitative method & $\begin{array}{l}\text { The concepts education, ob } \\
\text { stacles for female educatio } \\
\mathrm{n} \text { and gender in/equality. }\end{array}$ & $\begin{array}{l}\text { Positive impact public spending } \\
\text { on schooling }\end{array}$ \\
\hline Stasavage (2005) & $\begin{array}{l}\text { 1980-1996, } 44 \text { African } \\
\text { countries }\end{array}$ & OLS estimates & Govt Spending & $\begin{array}{l}\text { Population, Aid, log GDP Per ca } \\
\text { pita, Election year, Multiparty c } \\
\text { ompetition }\end{array}$ \\
\hline $\begin{array}{l}\text { Alderman et al. (2001 } \\
\text { ) }\end{array}$ & $\begin{array}{l}\text { 1986-1991, } \\
\text { Pakistan }\end{array}$ & $\begin{array}{l}\text { explicit dynamic } \\
\text { model }\end{array}$ & price shocks & behavior child health \\
\hline $\begin{array}{l}\text { Gupta \& Verhoeven ( } \\
\text { 2001) }\end{array}$ & 1984-1995, Africa & $\begin{array}{l}\text { Free Disposal hull } \\
\text { analysis }\end{array}$ & $\begin{array}{l}\text { Govt Spending on edu and } \\
\text { health }\end{array}$ & $\begin{array}{l}\text { purchasing power parity, GDP a } \\
\text { nd social Indicator }\end{array}$ \\
\hline Arif et al. (1999) & 1998-1999, Pakistan & $\begin{array}{l}\text { logit technique/M } \\
\text { odel }\end{array}$ & enrolment & $\begin{array}{l}\text { Age, gender, rural/urban area, } \mathrm{p} \\
\text { arents' education, household inc } \\
\text { ome, poverty, farm status, and re } \\
\text { mittance. }\end{array}$ \\
\hline Brown (1999) & $\begin{array}{l}\text { 1960-1985, } 136 \text { Develo } \\
\text { ping countries. }\end{array}$ & $\begin{array}{l}\text { dichotomous and } \\
\text { continuous model } \\
\mathrm{S}\end{array}$ & primary school enrolment & $\begin{array}{l}\text { Income, democracies, and GD } \\
\mathrm{P} \text { per capita. }\end{array}$ \\
\hline Poterba (1997) & $\begin{array}{l}\text { 1960-1990, United Stat } \\
\text { es }\end{array}$ & $\begin{array}{l}\text { median-voter mod } \\
\text { el, regression mod } \\
\text { el }\end{array}$ & $\begin{array}{l}\text { government spending on } \mathrm{p} \\
\text { er-child education }\end{array}$ & Education, schooling, growth \\
\hline
\end{tabular}




\section{Data And Methodology}

The study is based on the time series data from 2000 to 2017. Details of the variables and its sources are given in Table 3. Five variables are used in this study for finding the determinants of school Enrollment. There are two dependent variables, Primary school enrollment and Secondary School enrollment while GDP and Government expenditure and political stability independent variable areas.

Table 3: Variable's Description and Data Source

\begin{tabular}{lll}
\hline S.No. & Variable description & Data sources \\
\hline 1 & School enrollment, secondary (\% gross) & WDI ( 2020), World Bank \\
\hline 2 & "School enrollment, primary (\% gross): & WDI ( 2020), World Bank \\
3 & GDP growth rate (\%) (constant 2010 US\$) & WDI ( 2020), World Bank \\
4 & $\begin{array}{l}\text { General government final consumption expenditure (c } \\
\text { onstant 2010 US\$) }\end{array}$ & WDI ( 2020), World Bank \\
Political stability & $\begin{array}{l}\text { World Governance Indicators (2020), World B } \\
\text { ank }\end{array}$
\end{tabular}

\section{Empirical Model}

To examine the impact of government expenditure on school enrollment ((i.e. primary school enrollment, secondary school enrollment) of Pakistan, the following two regression models are used. The construction of the Primary school enrollment and Secondary school enrollment on the regression analysis the correlation analysis and finally the results of different tests as mentioned in research methodology.

We the ordinary least squares (OLS) method, which has also used by Poterba (1997), and Brown (1999) and which can be written as follow:

$\mathrm{PSE}=+\beta 1 \mathrm{GE}+\beta 2 \mathrm{GDP}+\beta 3 \mathrm{PS}+\varepsilon$

Where in equation 1, PSE shows the primary school enrollment, GE shows that Government expenditure, GDP shows the Gross domestic product of Pakistan and $\varepsilon$ is the error term.

$\mathrm{SSE}=+\beta 1 \mathrm{GE}+\beta 2 \mathrm{GDP}+\beta 3 \mathrm{PS}+\varepsilon$

Where in equation 2, SSE shows the secondary school enrollment which is dependent, while the independent variables as GE shows that Government expenditure, GDP shows the Gross domestic product of Pakistan and $\varepsilon$ is the error term.

\section{Estimation Techniques}

The method of Least Squares (OLS) is implemented because it is one of the easiest techniques of linear regression. The goal of OLS is to closely "fit" a function with the data. It is minimizing the sum of squared errors from the data. "The OLS method is also used in that time when there is no trend in the data. The statistical properties of OLS are based on the assumptions of CLRM (classical linear regression model)." Similar methods are also used by many studies such as Poterba (1997), and Stasavage (2005).

\section{Result And Discussions}

In order to conduct a time series analysis of certain macro-economic variables (GDP, Government expenditure) trying to influence their effect on Primary school and secondary school enrollment in Pakistan. Multiple variable analyses were conducted using the software "EVIEWS". Basically, the regression plots, the line of best fit, or, the least square line, where the relationship between the independent variables and the dependent variable is the strongest. The 
main values from the regression which will be focused upon in our analysis are R-Squared, PValue \& Z-Statistic.

In this study, we cannot use a unit root test because the time period is less. If the time period is less than 30 years than no need for a unit test. "Descriptive statistics results are given in Table 4.The descriptive statistics help to give us the analysis of data signify or summarize data in a meaningful way or a set of brief statistics that signify measure of significant tendency include mean, median, standard deviation, minimum, maximum variables, kurtosis and skewness." The descriptive statistics are very essential because if we simply presented a time series data it would be difficult visualize what the data are shown more a lot of it enable us to represent the data in a more meaningful way which is show simpler interpretation of the data.

Table 4: Descriptive Statistics

\begin{tabular}{lllll}
\hline Statistics variables & \multicolumn{1}{c}{ PSE } & SSE & GE & GDP \\
\hline Mean & 88.76 & 32.56 & 1.74 & 1.75 \\
Median & 91.10 & 35.084 & 1.83 & 1.75 \\
Maximum & 97.75 & 46.10 & 2.70 & 2.41 \\
Minimum & 74.61 & 18.08 & 8.84 & 1.20 \\
Std. Dev & 7.210 & 8.67 & 5.57 & 3.58 \\
Skewness & -0.78 & -0.229 & 0.02 & 0.14 \\
Kurtosis & 2.50 & 1.88 & 1.97 & 2.15 \\
Jarque-Bara & 1.936 & 1.03 & 0.74 & 0.56 \\
Probability & 0.37 & 0.59 & 0.68 & 0.75 \\
Sum & 1509 & 553.53 & 2.96 & 2.97 \\
Sum sq. Dev & 831.88 & 1203 & 4.97 & 2.05 \\
Observations & 17 & 17 & 17 & 17 \\
\hline
\end{tabular}

\section{Regression Results}

The regression line that explains the exact relationship between the selected independent variables and the two dependent variable which is Secondary school enrollment and Primary school enrollment show below in the Table 5. So in the regression Table 5 the results of explanatory variables in the model are found statistically significant because the $\mathrm{P}$ value is less than $(0.05 \%)$ which is $(0.000)$ meaning that the relationship between school enrollment and GDP is significant. LnGDP (+) sign. Results of GDP shows positive relationship with both dependent variables in this study. These results are matching with the results of Arif et al., 1999) for Pakistan. The finding implies that one unit change increase GDP brings (1.56) in secondary school and (0.79) increase in primary school enrollment. G_exp (+) sign shows that govt expenditure has also positive

relationship with school enrollment. The finding implies that one unit change increase in Govt expenditure brings increase in school enrollment. While one unit increase in Political stability (pol_s) it will decrease the school enrollment in 0.10 units. The analysis suggests that Govt expenditure and political stability has negatively affected the school enrollment in Pakistan. We can also see the value of R-square which is greater than (0.90) meaning that $98 \%$ and $93 \%$ are Xvariables have been explained during the study or estimation. $\mathrm{R}^{2}$ which is greater than $60 \%$ means that we accept the model if it is less than $60 \%$ than reject the model. Overall results are matching with the results of Stasavage (2005); Arif et al. (1999); Abu et al. (2014); Ali and Muhammad (2016); Khan et al (2016; 2014), and Khan and Haseeb (2017). 


\begin{tabular}{|c|c|c|c|c|c|c|c|c|}
\hline \multirow{3}{*}{ variables } & \multicolumn{7}{|c|}{ Table 5: Regression result } & \multirow[b]{3}{*}{ Prob. } \\
\hline & \multicolumn{3}{|c|}{ Dependent Variable is SSE } & \multicolumn{4}{|c|}{ Dependent Variable is PSE } & \\
\hline & coeff & stnd.error & Z-stat & Prop. & coeff & stnd.error & z-stat & \\
\hline LNGDP & 1.565 & 0.2694 & 5.808 & 0.0000 & 0.795 & 0.1618 & 4.9144 & 0.0002 \\
\hline G_EXP & $1.87 \mathrm{E}-11$ & $9.93 \mathrm{E}-12$ & 1.881 & 0.0805 & $2.09 \mathrm{E}-11$ & $5.93 \mathrm{E}-12$ & 3.525 & 0.0034 \\
\hline POL_S & -0.164 & 0.041 & -3.963 & 0.0014 & -0.063 & 0.0248 & -2.545 & 0.0233 \\
\hline \multirow[t]{14}{*}{ Constant } & -37.09 & 6.7780 & -5.472 & 0.000 & -15.869 & 4.070 & -3.8985 & 0.0016 \\
\hline & R-Squares & 0.98 & & & 0.93 & & & \\
\hline & Mean dep var & 3.41 & & & 4.47 & & & \\
\hline & $\begin{array}{l}\text { Adjusted R-squa } \\
\text { red }\end{array}$ & 0.98 & & & 0.92 & & & \\
\hline & $\begin{array}{l}\text { S.D. dependent } \mathrm{v} \\
\text { ard }\end{array}$ & 0.31 & & & 0.09 & & & \\
\hline & $\begin{array}{l}\text { S.E. of regressio } \\
\mathrm{n}\end{array}$ & 0.04 & & & 0.02 & & & \\
\hline & $\begin{array}{l}\text { Akaike info crite } \\
\text { rin }\end{array}$ & -3.29 & & & -4.32 & & & \\
\hline & $\begin{array}{l}\text { Sum squared resi } \\
\text { d }\end{array}$ & 0.02 & & & 0.00 & & & \\
\hline & schwarz criterion & -3.09 & & & -4.13 & & & \\
\hline & Log likelihood & 33.65 & & & 42.9 & & & \\
\hline & $\begin{array}{l}\text { Hannan-Quinn c } \\
\text { riter }\end{array}$ & -3.26 & & & -4.30 & & & \\
\hline & F-statistic & 309 & & & 71.0 & & & \\
\hline & $\begin{array}{l}\text { Durbin-Watson s } \\
\text { tat }\end{array}$ & 1.24 & & & 1.46 & & & \\
\hline & Prob(F-statistic) & 0.000 & & & 0.000 & & & \\
\hline
\end{tabular}

\section{Summary and Conclusion}

Our main finding in this study is that gross domestic product is positively significant to school enrollment of Pakistan. The government expenditure has significantly positive effects on school enrollment of Pakistan, while political stability (PS) has negative effect on school enrollment. After that, we estimated the variable individually with the dependent variable. We have collected data from different sources. For all these results we use OLS technique. The main purpose of the study is to evaluate the effect of Government expenditure on School enrollment of Pakistan. Based on secondary data for the period of 2000 to 2017. In this study we used two dependent variables. Primary School enrollment and Secondary School enrollment. For obtaining the empirical results we employed the least squares method. The empirical finding revels that national income (GDP) has positive relation with the school enrollment. Government expenditure and Political stability has positive effects of school enrollment which has conform as our hypothesized. The policy makers and the government of Pakistan is required to increase government on education and increase school enrolment in the country.

\section{References}

Abu, B. N. A. Haseeb, M., \& Azam, M., (2014). The nexus between education and economic growth in Malaysia: cointegration and Toda-Yamamoto causality approach. Actual Problems of Economics, 12(162), 131-141

Ali, S. R., \& Muhammad, A., (2016). Do workers' remittances boost human capital development? The Pakistan Development Review, 55 (2), 123-149 
Alderman, H., Behrman, J. R., Lavy, V., \& Menon, R. (2001). Child health and school enrollment: A longitudinal analysis. Journal of Human resources, 185-205.

Alderman, H., Orazem, P. F., \& Paterno, E. M. (2001). School quality, school cost, and the public/private school choices of low-income households in Pakistan. Journal of Human resources, 304-326.

Arif, G. M., us Saqib, N., Zahid, G. M., \& Khan, A. H. (1999). Poverty, Gender, and Primary School Enrolment in Pakistan [with Comments]. The Pakistan Development Review, 979992.

Akbar, H., Khan, F., Khan, M., \& Bibi, W., (2021). An Analysis of teaching methodologies of the female english teachers in the public and private secondary schools in district Bannu, Khyber Pakhtunkhwa, Pakistan. Elementary Education Online, 20 (Issue 5): 1500-1508

Azam, M. \& Ahmad, M. A., (2015). Role of human capital and foreign direct investment in promoting economic growth: Evidence from Commonwealth of Independent States. International Journal of Social Economics, 42(2), 89-111

Azam, M. (2016). Does governance and foreign capital inflows affect economic development in OIC countries? Journal of Economic Cooperation and Development, 37(4) 21-50

Azam, M. (2021). Governance and economic growth: evidence from 14 Latin America and Caribbean countries. Journal of the Knowledge Economy, https://doi.org/10.1007/s13132021-00781-2

Azam, M. \& Feng, Y. (2021). Does foreign aid stimulate economic growth in developing countries? Further evidence in both aggregate and disaggregated samples. Quality and Quantity, DOI: 10.1007/s11135-021-01143-5

Azam, M. (2020). Energy and economic growth in developing Asian economies. Journal of the Asia Pacific Economy, 25(3), 447-471

Azam, M., Khan, H. \& Khan, F. (2020). Testing Malthusian's and Kremer's population theories in developing economy, International Journal of Social Economics, 47(4), 523-538

Brown, D. S. (1999). Reading, writing, and regime type: democracy 'impact on primary school enrollment. Political Research Quarterly, 52(4), 681-707.

Craigwell, R., Bynoe, D., \& Lowe, S. (2012). The effectiveness of government expenditure on education and health care in the Caribbean. International Journal of Development Issues, 11(1), 4-18,

Faizi, W. N., Bibi, W., Khan, F. (2020). Educational policies (1947-2009) of Pakistan and integration of Islamic values among secondary level learners: an evaluative study. Pakistan Journal of Humanities \& Social Sciences Research, 03(01), 79-90

Government of Pakistan, Economic Survey of Pakistan (Various Issues), Ministry of Finance, Islamabad-Pakistan

Gupta, S., \& Verhoeven, M. (2001). The efficiency of government expenditure: experiences from Africa. Journal of Policy Modeling, 23(4), 433-467.

Haseeb, M., \& Azam, M. (2021). Dynamic nexus among tourism, corruption, democracy and environmental degradation: a panel data investigation. Environment, Development and Sustainability, 23, 5557-5575

Khan, F., \& Irshad (2018). The effect of education and good trained teachers on students' performance. PUTAJ - Humanities and Social Sciences, 25(2), 93-99

Khan, F., Fauzee M.S. O., \& Daud, Y., (2016). Education, teacher training, problems and challenges: A comparative study between India and Pakistan. Gomal University Journal of Research, (Special Issue II June 2016), 1-12)

Khan F., \& Haseeb, M. (2017). Analysis of teacher training education program: a comparative study of Indonesia, Malaysia and Pakistan. Paradigms, 11(1), 13-17

Khan, F., Javeria U., \& Numan, M. (2014). Education, foreign direct investment and socioeconomic development-A review. Abasyn Journal of Social Sciences, 7 (2), 269- 
277Memon, G. R. (2007). Education in Pakistan: The key issues, problems and the new challenges. Journal of Management and Social Sciences, 3(1), 47-55.

Khaliq, F. \& Ahmad, W. (2016). Quality and Effectiveness of Public Spending on Education in Pakistan. SBP Staff Notes 02/16. State Bank of Pakistan, Karachi. Retrieved from http://www.sbp.org.pk/publications/staff-

notes/QualityEffectivenessPublicEducationSpendingEducationPakistan.pdf

Muhammad A., \& Chandra, E., (2014). The role of Governance in economic development: Evidence from Some Selected Countries in Asia and the Pacific. International Journal of Social Economics, 41(12), 1265-1278

Muhammad, A., Khan, S., Zainal, Z., Karuppiah, N., \& Khan, F., (2015). The impact of foreign direct investment on human capital in developing countries. Investment Management and Financial Innovations, 12(3): 155-162

Muhammad, A., (2015). The role of migrant workers remittances in fostering economic growth: The four Asian developing country's experiences. International Journal of Social Economics, 42(8), 1-18

Poterba, J. M. (1997). Demographic structure and the political economy of public education. Journal of Policy Analysis and Management: The Journal of the Association for Public Policy Analysis and Management, 16(1), 48-66.

Rehman, Z, Tariq, M, \& Azam, M. (2018). The role of human capital in economic development in the selected Central Asian countries. The Dialogue, XIII(03), 235-244

Rehman, L., \& Khan, F. (2021). An analysis of out of schoolchildren factors: A case study of Pakistan. Journal of Social transformation and Education, 2 (1), 10-25

Sajjad, I., Bilal, M., \& Muhammad, K. A., (2018). Investigating the impact of external debt on economic growth: a case study of Pakistan. Journal of Business and Tourism, 4(2), 53-63

Stasavage, D. (2005). Democracy and education spending in Africa. American journal of political science, 49(2), 343-358.

Shayan, Z. (2015). Gender inequality in education in Afghanistan: Access and barriers. Open Journal of Philosophy, 5(05), 277.

Tripathi (2014), Sanjay Tripathi. Retrieved from Importantindia: https://www.importantindia.com/10509/importance-of-education/

The Education challenge: Human Development in South Asia. (1998). Human Development center, Islamabad

UNDP, 1. (1990). Human development report. New York: for the United Nations Development Programmed (UNDP).

http://www.pakistaneconomist.com/2018/05/14/educational-budget-fiscal-year-2018-19/

World Development Indicators (2020), World Bank

World Governance Indicators ( 2020), World Bank 